\title{
Detection and Confirmation of Potato mop-top virus in Potatoes Produced in the United States and Canada
}

\author{
H. Xu, T.-L. DeHaan, and S. H. De Boer, Canadian Food Inspection Agency, Centre for Animal and Plant Health, \\ 93 Mount Edward Road, Charlottetown, PEI, Canada, C1A 5T1
}

\begin{abstract}
Xu, H., DeHaan, T.-L., and De Boer, S. H. 2004. Detection and confirmation of Potato mop-top virus in potatoes produced in the United States and Canada. Plant Dis. 88:363-367.

Potato mop-top virus (PMTV) was detected in potatoes grown in the United States and Canada during surveillance testing by a reverse transcription-polymerase chain reaction (RT-PCR) targeting the coat protein gene in RNA3. Out of 3,221 lots of seed and ware potatoes that were tested, $4.3 \%$ were positive for PMTV. The reliability of the survey results was confirmed by reextraction of selected samples and additional RT-PCR tests using two primer sets targeting gene segments in RNA2 and RNA3. Amplicons generated from RNA2 and RNA3 were identified by analysis of fragment length polymorphisms after digestion with BamHI and HindIII, respectively. PMTV was further identified by enzyme-linked immunosorbent assay, bioassay on Nicotiana debneyi, and transmission electron microscopy. Sequencing of a portion of the coat protein gene revealed near $100 \%$ identity among isolates from the United States and Canada and $>97 \%$ homology of the North American isolates with European isolates.
\end{abstract}

Potato mop-top virus (PMTV), previously a member of the genus Furovirus, is now classified as the type member of the genus Pomovirus $(18,27)$. PMTV is an important pathogen of potato that can cause serious economic losses in susceptible cultivars $(5,23)$. The virus is transmitted via spores of Spongospora subterra$n e a$, the causal agent of powdery scab, and persists in soil in resting spores of the plasmodiophoromycete for many years (8). PMTV causes a spraing disease (necrotic arcs in tuber flesh) of sensitive potato cultivars with symptoms similar to those caused by the nematode-transmitted Tobacco rattle virus (TRV, a tobravirus) and potato tuber necrotic strain of Potato virus $Y$ (PVY ${ }^{\mathrm{NTN}}$, a potyvirus) (7). In addition to spraing, PMTV can cause a wide range of symptoms on potato foliage including stunting, mottling, chevrons, and yellow blotches or rings. The leaf symptoms can be easily confused with those induced by Alfalfa mosaic virus (an alfamovirus) and Potato aucuba mosaic virus (PAMV, a potexvirus).

PMTV is an example of a small group of viruses in which systemic movement is not dependent on coat protein (CP) expression or virion formation (13). The triplegene block (TGB) proteins encoded by PMTV RNA2 represent a class of long-

Corresponding author: H. Xu

E-mail: xuh@inspection.gc.ca

Accepted for publication 21 November 2003.

Publication no. D-2004-0120-01R

(C) 2004 Minister of Agriculture and Agri-Food, Government of Canada distance RNA movement factors that mobilizes naked but infectious viral RNA $(6,14)$. Not all plant parts infected with viral RNA, therefore, contain assembled virions. Naked RNA may be present in symptomless tubers and cause secondary infection the following season. The sporadic and highly irregular distribution of PMTV virions in infected plants may also explain, in part, the high variability in symptomology, as the $\mathrm{CP}$ is required for symptom expression (13).

Detection methods based on the enzyme linked immunosorbent assay (ELISA) and reverse transcription-polymerase chain reaction (RT-PCR) have been evaluated for screening potato tubers for the presence of PMTV $\quad(2,16,19,26)$. Oligonucleotide primers used for detection by RT-PCR target the CP gene of PMTV RNA3 and TGB operon of RNA2 because these two regions are considered to be highly conserved $(3,12,20,24)$. To increase PMTV concentration in potatoes for enhanced detection, it has been suggested that tubers be stored at an elevated temperature for a few weeks or subjected to a fluctuating temperature regime prior to testing (25). However, accurate detection of PMTV remains problematic.

PMTV is known to occur in the Andean region of South America and in northern Europe. Its occurrence in private gardens in Canada was noted previously (J. D. McDonald, personal communication), but commercial production of potatoes was considered to be free of PMTV in both Canada and the United States. Recently, however, potatoes with PMTV symptoms were discovered in the United States and presence of the virus confirmed by ELISA and RT-PCR (10). We also detected PMTV in potatoes imported from the United States into Canada as well as in potatoes produced in Canada, but without having observed the presence of PMTV symptoms. To establish with certainty that PMTV was present in tubers that did not express clear symptoms of PMTV, we applied a combination of methods involving serological, molecular, and biological tests. In this paper we report on the efficacy of the various methods we employed for confirming and verifying the presence of the virus. In addition, we report on the similarity of the $\mathrm{CP}$ gene sequence of North American and European isolates of PMTV and on the selection of primers for RT-PCR amplification of PMTV RNA.

\section{MATERIALS AND METHODS}

Potato tuber samples. Tubers from 3,221 different lots of seed and ware potatoes originating from various sources in the United States and Canada were assayed in 2001 and 2002. The tubers were collected from various storages and transport trucks but were kept at room temperature or $4^{\circ} \mathrm{C}$ upon arrival at the laboratory. Tubers were sampled by removing a 0.5 -g cone of tissue $(1 \mathrm{~cm}$ deep and $1 \mathrm{~cm}$ in diameter) from the stolon (or heel) end of dormant tubers. For tubers that had broken dormancy, the tissue core was taken from the bud (or rose) end. Sampled tubers were maintained on pegboards to permit resampling of selected tubers as required. Cores from 2 to 25 tubers, depending on the sample size, were combined into composite samples for processing and testing. All samples were macerated in extraction bags (Bioreba AG, Reinach, Switzerland) by pounding the tissue with a hammer, and then extracted and subjected to a RT-PCR test as described below. A portion of the RTPCR-positive samples were subjected to a second extraction and RT-PCR test, followed by analyses of restriction fragment length polymorphisms (RFLP) in the amplicon to confirm the initial positive results. Tubers from confirmed positive samples, selected on the basis of geographic origin of the sample, were grown out in a greenhouse for further testing. Plants generated in the grow-outs were tested for PMTV by ELISA, RT-PCR, bioassay on an indicator host plant, and transmission electron microscopy (TEM) as described below. 
RT-PCR. From each macerated sample, $100 \mu \mathrm{l}$ of sap was extracted with the TriReagent (Molecular Research Center, Inc., Cincinnati, $\mathrm{OH}$ ) as described by the manufacturer. Subsequently, the RNA was extracted with chloroform, precipitated with isopropanol, washed with ethanol, and suspended in $25 \mu \mathrm{l}$ (for tuber samples) or $50 \mu \mathrm{l}$ (for leaf samples) of RNase-free and DNase-free water according to standard

Two sets of primers were used for testing by RT-PCR. Primers C819 (complementary to bases 797 to 819 ) and H360 (homologous to bases 360 to 382) targeted the CP gene of PMTV RNA3 (11) (Table 1). Primers pmtF4 (homologous to bases 1727 to 1747) and pmtR4 (complementary to bases 2121 to 2143) were designed in this study on the basis of known sequences of PMTV RNA2 (GenBank accession no. NC_003725, AJ277556, D30753) (Table 1). Primer set $\mathrm{C} 819 / \mathrm{H} 360$ was used in RT-PCR for screening tests, while primer set pmtF4/R4 was used for confirmatory tests.

The first strand cDNA synthesis was carried out using Moloney murine leukemia virus (M-MLV) reverse transcriptase (Invitrogen Canada, Burlington, Canada) using the antisense primer. Two microliters of the RNA extract was used in a total reaction volume of $20 \mu \mathrm{l}$ containing the first strand DNA synthesis buffer supplied with the M-MLV RT as well as $50 \mu \mathrm{M}$ of each dNTP (Invitrogen Canada, Burlington, Canada) and $0.5 \mu \mathrm{M}$ of primer. The reaction was run at $37^{\circ} \mathrm{C}$ for $60 \mathrm{~min}$. One microliter of the cDNA solution was then procedures (22).

amplified in a total volume of $25 \mu \mathrm{l}$ containing $2.5 \mathrm{mM} \mathrm{MgCl}, 0.2 \mathrm{mM}$ of each dNTPs, $0.1 \mu \mathrm{M}$ of each sense and antisense primer, and 2.5 units of Taq DNA polymerase (Qiagen Inc., Mississauga, Canada) in a buffer supplied with the polymerase. The temperature regime for amplification reactions was: initial denaturation for $5 \mathrm{~min}$ at $94^{\circ} \mathrm{C}$, followed by 35 cycles of $95^{\circ} \mathrm{C}$ for $1 \mathrm{~min}, 64^{\circ} \mathrm{C}$ for $1 \mathrm{~min}$, and $72^{\circ} \mathrm{C}$ for $1 \mathrm{~min}$. The final extension was at $72^{\circ} \mathrm{C}$ for $5 \mathrm{~min}$. A PTC-100 thermocycler (MJ Research, Inc., Watertown, MA) was used for screening tests, and a Thermolyne Amplitron II thermocycler (Thermolyne Ltd., Dubuque, IA) was used for confirmatory testing. PCR products were separated on a $1.2 \%$ agarose gel, stained with ethidium bromide, and visualized under UV light.

Restriction digestion. PCR amplicons generated with the H360/C819 and pmtF4/R4 primer sets were digested with HindIII and BamHI, respectively. Fivemicroliter amplicons were digested with 5 units of the restriction enzyme at $37^{\circ} \mathrm{C}$ for $1 \mathrm{~h}$ in a reaction volume of $20 \mu \mathrm{l}$ using the buffer recommended by the enzyme supplier (New England Biolabs, Mississauga, Canada). RFLPs were analyzed by agarose gel electrophoresis using 2\% agarose- 1000 (Invitrogen Canada, Burlington, Canada) stained with ethidium bromide and visualized under UV light.

ELISA. Potato tubers, leaves, and indicator plant leaves were screened for the presence of PMTV by standard triple antibody sandwich ELISA using a commercial kit, Identikit with the Adgen Blue substrate (Adgen Ltd., Auchincruive, UK), follow-

Table 1. Primer pairs used in reverse transcription-polymerase chain reaction (RT-PCR) amplification of Potato mop-top virus (PMTV) RNA in this study

\begin{tabular}{llccc}
\hline Primer pair & \multicolumn{1}{c}{ Sequence } & Product & Target & Ref. \\
\hline C819 & 5'-CTATGCACCAGCCCAGCGTAACC-3' & $460 \mathrm{bp}$ & Coat protein & 11 \\
H360 & 5'-CATGAAGGCTGCCGTGAGGAAGT-3' & & & \\
pmtF4 & 5'-CAGCAACCACAAACAGACAGG-3' & 417 bp & RNA 2 & This study \\
pmtR4 & 5'-AAGCCACTAACAAAACATACTGC-3' & & & \\
pmt1 & 5'-T CTCGGATACCAC CCT TGGA-3' & 553 bp & Coat protein & This study \\
pmt2 & 5'-CTATGCACCAGCCCAGCGT-3' & & & \\
\hline
\end{tabular}

Table 2. Detection of Potato mop-top virus (PMTV) by triple antibody sandwich enzyme-linked immunosorbent assay (ELISA) and reverse transcription-polymerase chain reaction (RT-PCR) in bulked samples in which tissue from PMTV-infected tubers was combined with tissue from healthy tubers at different ratios to form composite samples

\begin{tabular}{llllll}
\hline & \multicolumn{5}{c}{ Ratio of diseased to healthy tissue } \\
\cline { 2 - 6 } Parameter & $\mathbf{1 : 0}$ & $\mathbf{1 : 1 0}$ & $\mathbf{1 : 2 5}$ & $\mathbf{1 : 5 0}$ & $\mathbf{1 : 1 0 0}$ \\
\hline ELISA & & & & & \\
Mean & $1.003^{\mathrm{a}}$ & 0.209 & 0.071 & 0.029 & 0.011 \\
SD $^{\mathrm{b}}$ & 0.807 & 0.174 & 0.086 & 0.039 & 0.02 \\
RT-PCR & & & & & \\
Mean & $2.7^{\mathrm{c}}$ & 2 & 1.9 & 1.9 & 0.9 \\
SD & 0.5 & 0.6 & 0.7 & 0.7 & 0.7 \\
\hline
\end{tabular}

a Mean absorbance minus background.

${ }^{\text {b }}$ Standard deviation $(n=7)$.

${ }^{\mathrm{c}}$ Visual rating of amplicon band in gel electrophoresis on a scale of 0 to 3: $0=$ no visible band, $1=$ weakly visible band, 2 = moderate band, $3=$ strong band. ing the procedures recommended by the supplier. Tuber or leaf tissues were homogenized in $1 \times$ phosphate buffer containing $0.02 \% \mathrm{NaN}_{3}, 0.1 \%$ Tween 20 , and $0.1 \%$ skim milk powder ( $\mathrm{pH} 7.4)$ at a sample to buffer ratio of $1: 5$ or $1: 10$, and 100 $\mu \mathrm{l}$ of extracted sap was loaded in duplicate on microtiter plates. A panel of positive, negative, and buffer controls, in addition to the controls supplied with the kit, were included on each plate. A value of $2.5 \times$ the healthy control reading was used as the positive threshold, but if absorbance of the healthy control was $<0.040$, a positive threshold of 0.100 was used.

Grow-out and bioassay tests. Selected tubers were grown in a commercial soil mix in a greenhouse at $15^{\circ} \mathrm{C}$ for 4 to 6 weeks. Foliage was observed biweekly for symptoms and tested for the presence of PMTV by ELISA and RT-PCR as described above. Leaf sap ( $1 \mathrm{~g}$ per $5 \mathrm{ml}$ of phosphate buffer, $\mathrm{pH}$ 7.2) was also inoculated to leaves of the indicator host plant, Nicotiana debneyi, by mechanical rubbing with Carborundum powder. Indicator plants were grown in a greenhouse at $15^{\circ} \mathrm{C}$. Inoculated $N$. debneyi plants were observed for virus symptoms and tested for PMTV by ELISA and RT-PCR regardless of whether or not symptoms developed.

Electron microscopy. Leaves from the grow-out plants and inoculated $N$. debneyi plants were submitted to the Centre for Plant Health, Sidney, BC, Canada. The presence of PMTV-like particles was determined by immunocapture from leaf dips, negatively staining and visualization with a Hitachi H-7100 transmission electron microscope.

Sequencing. Two sets of primers, $\mathrm{H} 360 / \mathrm{C} 819$ and pmt1/pmt2, were used to generate amplicons for sequencing portions of the CP gene. Primers pmt1 (homologous to bases 268 to 288) and pmt2 (complementary to bases 801 to 820 ) were designed in this study (Table 1) on the basis of published sequences of the Scottish isolate T (9) and two Swedish isolates (Sw) (GenBank accession no. NC_003724 and AJ2243719). Pmt1/pmt2 was used for two isolates $(\mathrm{H} 2, \mathrm{H} 4)$ from Canadian potatoes and H360/C819 for one Canadian isolate (OT2) and three isolates (US450, US542, US834) from potatoes grown in the United States. Amplified DNA was purified with PEG 8000 followed by precipitation with $0.25 \mathrm{M} \mathrm{KAc}$ and 2 volumes of $95 \%$ ethanol. The PCR products were submitted for sequencing by the dye terminator cycle sequencing method (York University, Toronto, Canada). PMTV sequences were compared with the known sequences of PMTV isolates $\mathrm{T}$ and $\mathrm{S}$ from Scotland (GenBank accession no. D16193 and AJ224991), two isolates (Korneta and 54-10) from the Czech Republic (GenBank accession no. AF393507 and 478408), and two isolates ( $\mathrm{Sw} 1, \mathrm{Sw}$ ) from Sweden (GenBank accession no. NC_003724 and 
AJ243719). Sequences were aligned using Clone Manager (6.0) (Sci Ed Central, Durham, NC).

\section{RESULTS}

Preliminary RT-PCR tests. In preliminary tests, 460- or 417-bp amplicons were generated by RT-PCR using primer sets H360/C819 or pmtF4/R4, respectively, from RNA templates extracted from foliage and tubers of control plants infected with PMTV. RNA extracts from foliage of control plants infected with other viruses or viroid, including PAMV, Potato leafroll virus (PLRV, a polerovirus), Potato spindle tuber viroid (PSTVd), Potato virus $M$ (PVM, a carlavirus), Potato virus $X$ (PVX, a potexvirus), PVY common strain $\left(\mathrm{PVY}^{\mathrm{O}}\right), \mathrm{PVY}^{\mathrm{N}}$ strain, and TRV, were also tested in RT-PCR using these primer sets to determine specificity. None of them yielded amplification products. When template RNA extracted from leaf sap of PMTV-infected plants mixed with sap of plants infected with any of the other viruses, the expected 460-bp amplicon was obtained in RT-PCR with primer pair C819/H360.

To evaluate the sensitivity of the RTPCR test with primers C819/H360, sap from PMTV-infected tubers was mixed with sap from healthy tubers in a dilution series from 1:0 to 1:100. Readily detectable 460-bp amplicons were detected in samples with an infected:healthy ratio of 1:50 (Table 2). For PMTV surveillance testing, however, sample bulking ranged from to 2 to 25 cores per composite.

Surveillance testing. Potatoes from 30 presence of PMTV (Table 3). Potato lots for testing were selected on the basis of availability rather than on the basis of a statistically valid survey plan, invalidating any attempt to determine virus incidence or distribution on the basis of the data. The number of potato lots tested per state or province varied from 1 to 653 . Tubers for testing represented seed and ware (i.e., processing and tablestock) consignments originating from western, central, and eastern states and provinces of the United States and Canada. Although the origin of some of the potato lots was not determined with certainty, as some lots may have been trans-shipped via other states, it is clear provinces and states were tested for the

that PMTV was widely distributed throughout the United States and Canada. Of the 3,221 potato lots tested, 139 were positive for PMTV in the RT-PCR test (Table 3).

Confirmatory and verification tests. Individual tubers representing 33 different potato lots from 12 states/provinces that tested positive for PMTV in the initial screening test were retested to confirm the validity of the initial test and as a check for false positive results. RNA was reextracted from fresh tissue samples and amplified by RT-PCR using the C819/H360 primer set. In each case, RTPCR amplicons of 460 bp were obtained which digested into 160- and 300-bp fragments upon treatment with HindIII (Fig. 1). Retested samples that gave the expected RT-PCR and RFLP results were considered confirmed positive. Reextracted RNAs were also amplified with the pmtF4/R4 primer set, and the resulting amplicons of $417 \mathrm{bp}$ digested by BamHI yielded two fragments, 239 and 178 bp (Fig. 1).

Tubers representing 11 of the confirmed positive potato lots were planted in the greenhouse to produce foliage for further testing. Symptoms of PMTV were not observed on the potato foliage. However, PMTV was detected by ELISA in five of the grow-out plants (Table 4). The foliage from the ELISA-positive plants was also positive for PMTV by RT-PCR and confirmed by RFLP analysis of the amplicon. Indicator $N$. debneyi plants inoculated with leaf sap from the ELISA-positive plants developed a blotchy mosaic, not entirely characteristic of PMTV. The presence of PMTV in these indicator plants, however, was confirmed by ELISA and RTPCR/RFLP. The presence of PMTV-like rods in the 100 to $150 \mathrm{~nm}$ and 250 to 300 $\mathrm{nm}$ length ranges were observed by TEM in samples prepared from two of the growout potato plants and all the indicator host plants (Table 4). Some progeny tubers produced on grow-out plants developed spraing symptoms after 4 weeks in storage at 4 to $8^{\circ} \mathrm{C}$ (Fig. 2).

Sequence analysis. The complete coat protein gene sequence of Canadian isolate $\mathrm{H} 2$ was deposited in GenBank as accession AY327117. Portions of the PMTV CP gene sequences of the North American

Table 3. Incidence of Potato mop-top virus (PMTV) detection in the western, central, and eastern zones of the United States and Canada

\begin{tabular}{lcrc}
\hline & $\begin{array}{c}\text { Number of states and } \\
\text { provinces tested }\end{array}$ & \multicolumn{2}{c}{ Number of potato lots } \\
\cline { 3 - 4 } Zone $^{\text {a }}$ & 10 & Tested & Positive for PMTV \\
\hline Western & 8 & 1,133 & 29 \\
Central & 12 & 163 & 34 \\
Eastern & Unknown & 1,859 & 76 \\
Unknown & 30 & 66 & 0 \\
Total & 3,221 & 139 \\
\hline
\end{tabular}

${ }^{a}$ Zones correspond approximately, but not entirely, to Pacific plus Mountain time zone, Central time zone, and Eastern plus Atlantic time zone for the western, central, and eastern zones, respectively. isolates based on either primer pair C819/H360 or $\mathrm{pmt} 1 / \mathrm{pmt} 2$ shared $>97 \%$ identity with four European isolates. Despite the fact that all the sequences of the analyzed portion of the $\mathrm{CP}$ gene were very similar, it was clear that the sequence of two Canadian isolates ( $\mathrm{H} 2$ and $\mathrm{H} 4)$ more closely matched the sequence of the Swedish isolates ( $\mathrm{Sw} 1$ and $\mathrm{Sw}$ ) and the Czech isolates (54-10 and Kor) than a third Canadian (OT2) and the United States isolates (US450, 542, and 834) (Fig. 3).

\section{DISCUSSION}

Until this study was initiated, PMTV, a pest of quarantine status in both the United States and Canada, was believed to be absent from commercial potato production in North America (1). After it appeared that we detected PMTV in $4.3 \%$ of potato consignments during surveillance of imported and domestic potatoes in Canada, our study concentrated on unequivocal identification of PMTV in potatoes from North American sources. Although our results clearly indicated that the virus was widespread throughout the potato-growing regions of the United States and Canada (Table 3), the actual incidence and distribution could not be deduced from the data due to the irregular number of samples tested from any one area.

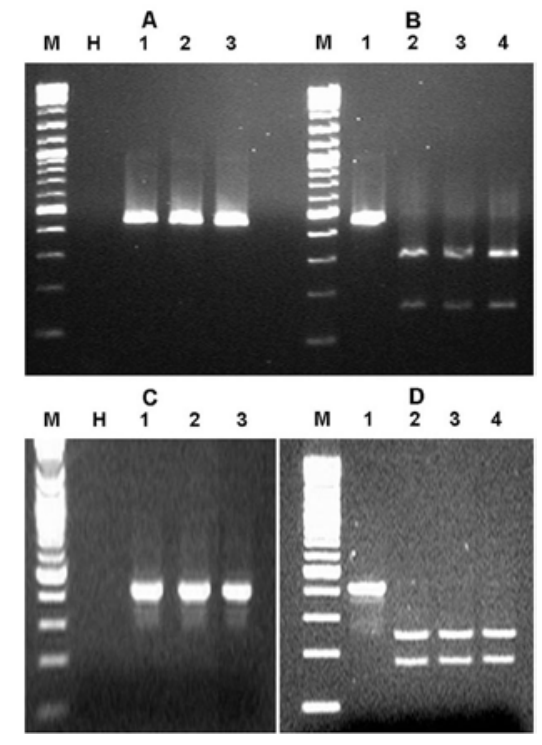

Fig. 1. Reverse transcription-polymerase chain reaction (RT-PCR) products obtained from RNA extracted from Potato mop-top virus (PMTV)-infected tubers and fragments obtained after digestion of PCR amplicons with restriction endonucleases. Initial RT-PCR tests were performed using primer set C819/H360, A, followed by HindIII digestion, $\mathbf{B}$, for confirmation of amplicon identity. Additional RT-PCR tests were performed using primer set pmtF4/R4, C, followed by BamHI digestion, $\mathbf{D}$. Lane $\mathrm{M}$, molecular size marker DNA; lane $\mathrm{H}$, RT-PCR product from healthy tubers (A and C); lanes A1-3 and C1-3, RT-PCR product from PMTV-infected tubers; lanes B2-4 and D2-4, amplicon digestion products; lanes B1 and D1, undigested products for comparison. 
The RT-PCR test was the basis of our indexing procedure. The procedure is costly and labor intensive compared with ELISA, which is used routinely for testing other potato viruses, but RT-PCR has the required sensitivity for a virus that is often present at low concentrations in the plant (2). The erratic distribution of the virus presented additional challenges to confirming and verifying the accuracy of the test results (25). Although RT-PCR is highly sensitive, it is also prone to false negative results due to the presence of PCR inhibitors in the RNA extracts, and to false positive results due to cross-contamination within the laboratory or priming with nonPMTV-derived DNA. In our study to show that PMTV was present in North American potatoes that did not express spraing symptoms, the challenge was to ensure that any positive results reflected the presence of actual virus in the sample. The consistent reproducibility of the RT-PCR tests of tissue re-extracted from potato tubers that were positive in the initial RT-PCR test suggested that initial positives were true positives and not due to crosscontamination from control extractions. Since the RT-PCR test used initially targeted the CP gene in RNA3, additional evidence for PMTV was obtained by a second RT-PCR using a primer set selected to target RNA2. The RFLP analysis of RTPCR amplicons was a necessary confirmation of amplicon identity-proof that the amplicons were indeed derived from PMTV genes.

Actual disease caused by PMTV in potato was not an issue at the commencement of our study, but subsequently, spraing symptoms typical of PMTV have been detected in both U.S.- and Canadian-grown potatoes (10; unpublished observation). At issue was the presence of the virus in asymptomatic potato tubers. In the absence of disease, Koch's postulates, the principle criteria for establishing disease etiology, were not directly applicable (4). Nevertheless, we followed the basic tenets of Koch's postulates to support the identification of PMTV.
Whether it was due to the greenhouse growing conditions or the tolerance of the potato cultivars, symptoms of PMTV were not evident on the foliage of plants grown from tubers positive for PMTV in RT-PCR. Furthermore, PMTV was detected in less than half of the grow-out plants, probably because of the uneven distribution of the

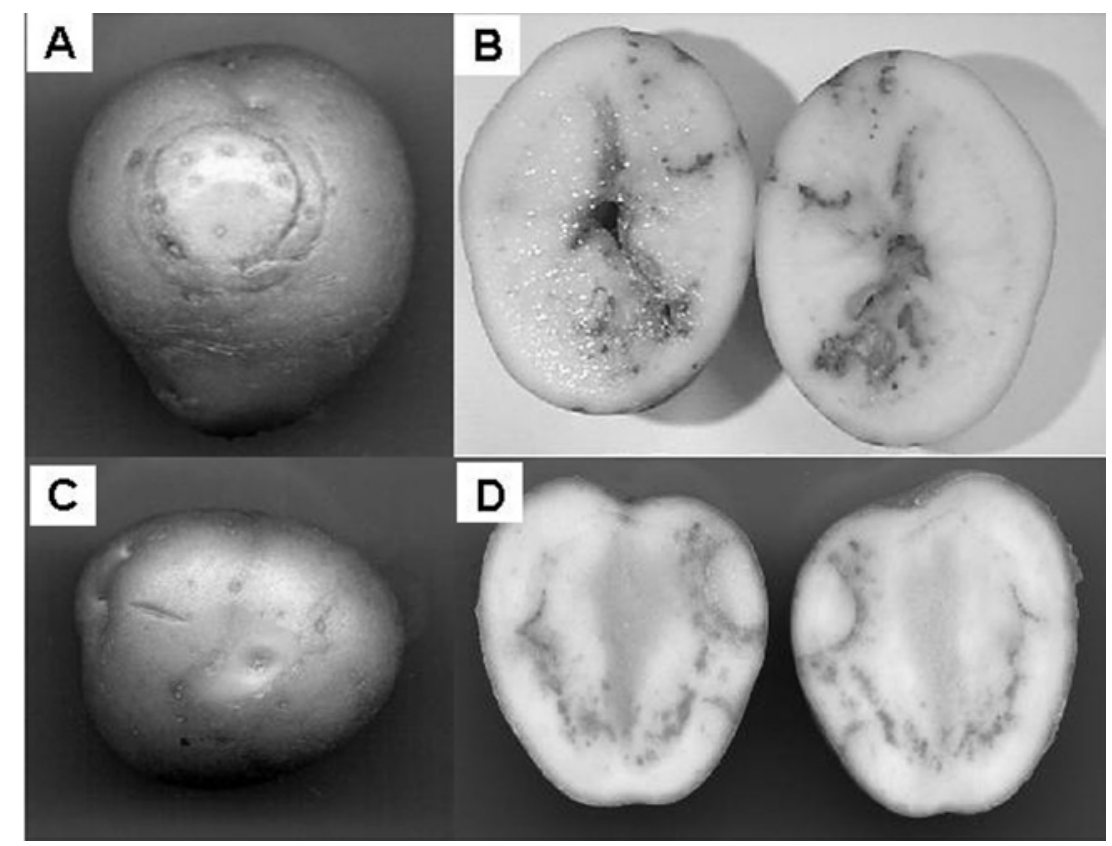

Fig. 2. Spraing symptoms on progeny potato tubers grown in the greenhouse (at 15 to $18^{\circ} \mathrm{C}$ ) from potato tubers (cv. Alpha) determined to be infected with Potato mop-top virus (PMTV). A and C, external symptoms. B and $\mathbf{D}$, internal symptoms.

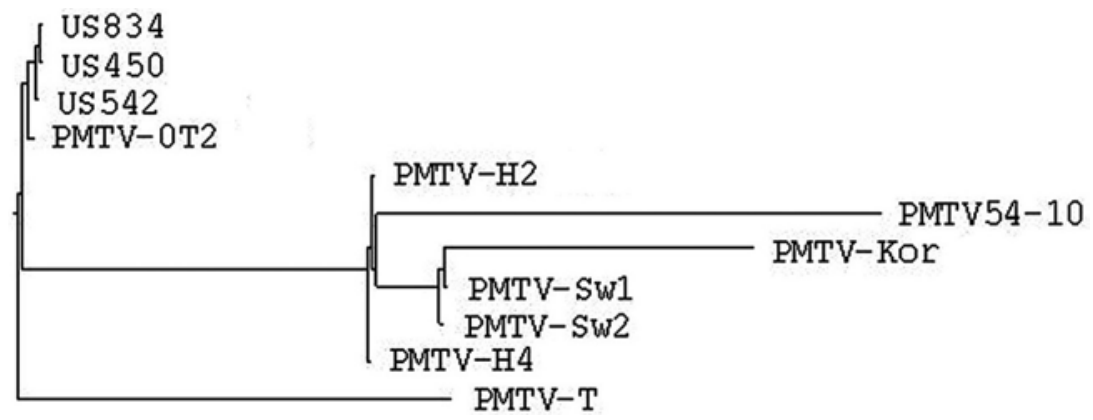

Fig. 3. Phylogram depicting the relationship among Potato mop-top virus (PMTV) isolates based on alignment of nucleotides in the coat protein gene. Multi-way DNA alignment was performed (Mismatch: 2 nucleotides; Open Gap: 4; Extended Gap: 1). PMTV isolates include one (T) from Scotland, two (Sw1 and Sw2) from Sweden, two (Kor and 54-10) from the Czech Republic, three (PMT2, PMT4, and OT2) from Canada, and three (US452, US450, and US834) from the United States.

Table 4. Results of series of tests conducted to verify the presence of Potato mop-top virus (PMTV) in selected potato tubers

\begin{tabular}{|c|c|c|c|c|c|c|c|c|}
\hline \multirow[b]{2}{*}{ Tuber number } & \multicolumn{4}{|c|}{ Tests applied to grow-out plants ${ }^{\mathrm{a}}$} & \multicolumn{4}{|c|}{ Tests applied to bioassay on Nicotiana debneyi } \\
\hline & Symptoms & ELISA & RT-PCR/RFLP & EM & Symptoms & ELISA & RT-PCR/RFLP & EM \\
\hline 1 & $-^{\mathrm{b}}$ & - & - & ND & ND & ND & ND & ND \\
\hline 2 & - & + & + & + & $+1-$ & + & + & + \\
\hline 3 & - & + & + & + & $+1-$ & + & + & + \\
\hline 4 & - & - & - & ND & ND & ND & ND & ND \\
\hline 5 & - & - & - & ND & ND & ND & ND & ND \\
\hline 6 & - & + & + & - & $+1-$ & + & + & + \\
\hline 7 & - & + & ND & ND & $+1-$ & + & + & + \\
\hline 8 & - & + & + & - & $+1-$ & + & + & + \\
\hline 9 & - & - & - & ND & ND & ND & ND & ND \\
\hline 10 & - & - & - & ND & ND & ND & ND & ND \\
\hline 11 & - & - & + & ND & ND & ND & ND & ND \\
\hline
\end{tabular}

${ }^{a}$ ELISA, enzyme-linked immunosorbent assay; RT-PCR, reverse transcription-polymerase chain reaction; RFLP, restriction fragment length polymorphism; EM, electron microscopy.

b -, negative for PMTV; +, positive for PMTV; +/-, suggestive or weakly positive for PMTV; ND, test not done. 
virus. In Europe, it is known that PMTVinfected seed tubers can give rise to uninfected stems (25). PMTV enters progeny tubers via the stolon (hence our targeting of the stolon end for sampling dormant tubers) and moves erratically through the rest of the tuber. Upon dormancy breaking, the virus presumably migrates to or multiplies in physiologically active tissue (hence our sampling of rose-end tissue for tubers that had broken dormancy), but there are no experimental data that support the perception of such movement, multiplication, and distribution of PMTV in potato tubers (15). It was not surprising, therefore, that only a fraction of the growout plants were infected with PMTV, since it is unlikely that PMTV is present in all eyes of infected tubers (25). Furthermore, the tubers used for grow-outs were in generally poor condition, having been sampled at least twice for laboratory testing. The positive ELISA results provided evidence for the presence of PMTV virions in the RT-PCR-positive grow-out plants, and infectivity was confirmed by disease development in inoculated indicator host plants. Characterization of PMTV by ELISA, RT-PCR, and TEM in some of the indicator plants established the identity of the virus unequivocally. Finally, the development of spraing symptoms on some tubers produced on grow-out plants fulfilled another tenet of Koch's postulates (4).

Cumulatively, our data provide adequate proof that PMTV is present in the North American commercial potato industry. However, the erratic confirmation of PMTV in plants grown from tubers that were positive for the virus by routine indexing exemplifies the difficulty that may be encountered in screening potato lots for the virus. In our study, we made no attempt to ascertain whether any false negative tests occurred, but evidence for nonuniform distribution of the virus in individual tubers suggests that the presence of the virus may not be detected in infected tubers unless multiple portions of the tuber are tested. Inconsistent ELISA and RTPCR test results have been reported previously $(2,15,17,25)$.

The sequences of the $\mathrm{CP}$ genes of PMTV isolates from Canada and the United States were essentially identical to one another and similar to those of European isolates (Fig. 3). Whether this similarity indicates a recent origin from Europe or is evidence of genetic stability was not determined. The wide distribution of PMTV (Table 3) suggests that it has been in the Canadian and U.S. industries for many years. Moreover, conservation of the coat protein gene sequence among isolates from Scotland, Scandinavia, and the Peruvian Andes has been reported (12,21). A uniform and stable $\mathrm{CP}$ gene will ensure that serological and molecular detection methods based on the coat protein are as effective for the North American strains as for the European and Andean strains.

\section{ACKNOWLEDGMENTS}

We thank the staff of the Diagnostic Laboratory, in particular Jane Gourley and Pam Ross, for their dedication and contribution to this study. The technical assistance of Jingbai Nie for some of the confirmatory work is gratefully acknowledged. We also thank Carol Masters of the Centre for Plant Health, Sidney, BC, Canada, for the electron microscopy work.

\section{LITERATURE CITED}

1. Anonymous. 1998. Requirements for the importation of potatoes into a NAPPO member country. Regional Standards for Phytosanitary Measures \#3. North American Plant Protection Organization.

2. Arif, M., Torrance, L., and Reavy, B. 1994. Improved efficiency of detection of potato mop-top furovirus in potato tubers and in roots and leaves of soil-bait plants. Potato Res. 37:373-381.

3. Beck, D. L., Guilford, P. J., Voot, D. M., Anderson, M. T., and Forster, R. L. S. 1991. Triple gene block proteins of white clover mosaic potexvirus are required for transport. Virology 183:695-702.

4. Bos, L. 1981. Hundred years of Koch's postulates and the history of etiology in plant virus research. Neth. J. Plant Pathol. 87:91-110.

5. Harrison, B. D., and Jones, R. A. C. 1970. Host range and some properties of potato moptop virus. Ann. Appl. Biol. 65:393-402.

6. Herzog, E., Hemmer, O., Hauser, S., Meyer, G., Bouzoubaa, S., and Fritsch, C. 1988. Identification of genes involved in replication and movement of peanut clump virus. Virology 248:312-322.

7. Jeffries, C. J. 1998. FAO/IPGRI Technical Guidelines for the Safe Movement of Germplasm: Potato. No. 19. Food and Agriculture Organization of the United Nations, Rome/International Plant Genetic Resources Institute, Rome.

8. Jones, R. A. C., and Harrison, B. D. 1972. Ecological studies on potato mop-top virus in Scotland. Ann. Appl. Biol. 71:47-57.

9. Kashiwazaki, S., Scott, K. P., Reavy, B., and Harrison, B. D. 1995. Sequence analysis of gene content of potato mop-top virus RNA 3: Further evidence of heterogeneity in the genome organization of furoviruses. Virology 206:701-706

10. Lambert, D. H., Levy, L., Mavrodieva, V. A., Johnson, S. B., Babcock, M. J., and Vayda, M. E. 2003. First report of Potato mop-top virus on potato from the United States. Plant Dis. 87:872.

11. MacKenzie, D. J. 1996. Detection of potato mop-top virus in leaf or tuber tissue by reverse transcription-polymerase chain reaction. Document CPHBT96K03, Centre for Plant Health, Agriculture and Agri-Food Canada, Sidney, B.C., Canada.

12. Mayo, M. A., Torrance, L., Cowan, G., Jolly, C. A., Macintosh, S. M., Orrega, R., Barrera, C., and Salazar, L. F. 1996. Conservation of coat protein sequence among isolates of potato mop-top virus from Scotland and Peru. Arch. Virol. 141:1115-1121.

13. McGeachy, K. D., and Barker, H. 2000. Potato mop-top virus RNA can move long distance in the absence of coat protein: Evidence from resistant, transgenic plants. Mol. Plant-Microbe Interact. 13:125-128.

14. Melander, M., Lee, M., and Sandgren, M. 2001. Reduction in potato mop-top virus accumulation and incidence in tubers of potato transformed with a modified triple gene block gene of PMTV. Mol. Breed. 8:197-206.

15. Mølgaard, J. P., and Nielsen, S. L. 1996. Influence of post harvest temperature treatments, storage period and harvest date on development of spraing caused by tobacco rattle virus and potato mop-top virus. Potato Res. 39:571579.

16. Mumford, R. A., Walsh, K., Barker, I., and Boonham, N. 2000. Detection of Potato mop top virus and Tobacco rattle virus using a multiplex real-time fluorescent reversetranscription polymerase chain reaction assay. Phytopathology 90:448-453.

17. Nielsen, S. L., and Mølgaard, J. P. 1997. Incidence, appearance and development of potato mop-top furovirus-induced spraing in potato cultivars and the influence on yield, distribution in Denmark and detection of the virus in tubers by ELISA. Potato Res. 40:101-110.

18. Pringle, C. R. 1999. Virus taxonomy - 1999. Arch. Virol. 144:421-429.

19. Rantanen, T., Lehtinen, U., and Kurppa, A. 1999. Development of a IC-RT-PCR test for the detection of potato mop-top virus. Pages 547-548 in: Proc. Trienn. Conf. Eur. Potato Assoc. 14th.

20. Reavy, B., Arif, M., Cowan, G. H., and Torrance, L. 1998. Association of sequences in the coat protein/readthrough domain of potato mop-top virus with transmission of Spongospora subterranean. J. Gen. Virol. 79:23432347.

21. Reavy, B., Sandgren, M., Barker, H., Heino, P., and Oxelfelt, P. 1997. A coat protein transgene from a Scottish isolate of potato mop-top virus mediates strong resistance against Scandinavian isolates which have similar coat protein genes. Eur. J. Plant Pathol. 103:829-834.

22. Sambrook, J., Fritsch, E. F., and Maniatis, T. 1989. Molecular Cloning: A Laboratory Manual, 2nd ed. Cold Spring Harbor Laboratory, Plainview, NY.

23. Sandgren, M., Plaisted, R. L., Watanabe, K. N., Olsson, S., and Valkonen, J. P. T. 2002 Evaluation of some North and South American potato breeding lines for resistance to potato mop-top virus in Sweden. Am. J. Potato Res. 79:205-210.

24. Scott, K. P., Kashiwazaki, S., Reavy, B., and Harrison, B. D. 1994. The nucleotide sequence of potato mop-top virus RNA 2: A novel type of genome organization for a furovirus. J. Gen. Virol. 75:3561-3568.

25. Sokmen, M. A., Barker, H., and Torrance, L. 1998. Factors affecting the detection of moptop virus in potato tubers and improvement of test procedures for more reliable assays. Ann. Appl. Biol. 133:55-63.

26. Torrance, L., Cowan, G. H., and Pereira, L. G. 1993. Monoclonal antibodies specific for potato mop-top virus and some properties of the coat protein. Ann. Appl. Biol. 122:311-322.

27. Torrance, L., and Mayo, M. A. 1997 Proposed reclassification of furoviruses. Arch. Virol. 142:435-439. 